\title{
Retarded development of XO conceptuses during early pregnancy in the mouse
}

\author{
P. S. Burgoyne, P. P. L. Tam* and E. P. Evans ${ }^{\dagger}$ \\ M.R.C. Mammalian Development Unit, 4 Stephenson Way, London NWI 2HE, and \\ †Sir William Dunn School of Pathology, South Parks Road, Oxford OX1 3RE, U.K.
}

\begin{abstract}
Summary. The growth and development of XO and XX mice were compared from $7 \frac{1}{4}$ to

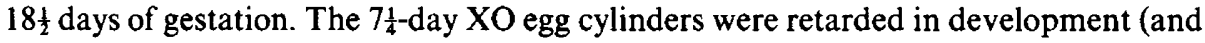
consequently small) when compared with XX egg cylinders, and this lag in development remained until $10 \frac{1}{2}$ days. By $12 \frac{1}{4}$ days there was a considerable degree of 'catch-up', but this was not fully maintained. A subgroup of very severely retarded XO fetuses were preferentially located near the cervix. The placentas of XO fetuses were of normal size until $18 \frac{1}{2}$ days when they were significantly larger than those of $\mathrm{XX}$ controls.
\end{abstract}

\section{Introduction}

The phenotype associated with X-chromosome monosomy is of particular interest since it indicates functions for the second $\mathrm{X}$ in normal females. The consequences of $\mathrm{X}$ monosomy have been most extensively studied in man and the mouse. XO women are typically of short stature, have streak ovaries, with consequent sexual infantilism and sterility, and are subject to a number of malformations (Simpson, 1976). In addition, there is a high fetal loss of XO females, only about $1 \%$ of those conceived surviving to term (see Polani, 1981), and those that do survive have a lower than average birth weight (Chen, Chan \& Falek, 1971; Polani, 1974). By contrast, XO mice were originally described as having an essentially normal phenotype (Welshons \& Russell, 1959; Cattanach, 1962). However, more recent work has revealed deficiencies in both the number (Burgoyne \& Baker, 1981a) and quality (Burgoyne \& Biggers, 1976) of oocytes and there are associated reproductive shortcomings (Lyon \& Hawker, 1973). XO mice also have a low birth weight and a reduced weight gain before weaning (Deckers \& van der Kroon, 1981; Burgoyne, Evans \& Holland, 1983).

The present study was undertaken to provide information on the aetiology of reduced birth weight.

\section{Mice}

\section{Materials and Methods}

Heterozygous $\operatorname{In}(\mathrm{X}) / \mathrm{X}$ mice were produced by mating males carrying the $\mathrm{X}$ inversion $\operatorname{In}(\mathrm{X}) 1 \mathrm{H}$ (Evans \& Phillips, 1975) to outbred MF1 albino females (Olac, Oxford). These $\operatorname{In}(\mathrm{X}) / \mathrm{X}$ females were then mated to MF1 males to provide litters in which about $25 \%$ of the females are XO (Phillips, Hawker \& Moseley, 1973). Litters were processed at ages ranging from $7 \frac{1}{4}$ to $18 \frac{1}{2}$ days post coitum. It was assumed that mating occurred in the middle of the dark period $(20: 00-06: 00 \mathrm{~h})$. The relative positions of individuals within each uterine horn were noted.

\footnotetext{
* Present address: Department of Anatomy, Chinese University of Hong Kong, Shatin, NT, Hong Kong.
} 


\section{Litters at $7 \frac{1}{4}$ days}

The conceptuses were removed during the morning of the 8th day of gestation and the egg cylinders were dissected out in $\mathrm{pH} 7.3$ phosphate-buffered saline. Individual embryos were transferred to a cavity slide, and an outline of the egg cylinder was drawn at a magnification of $\times 60$ using a Carl Zeiss microscope with camera lucida attachment. An assessment of the stage of development was recorded (i.e. early, mid or late primitive streak, or early neural plate). The diameter and length of the embryonic part of the egg cylinder were measured from the drawing and the embryonic volume was calculated by assuming approximation of the embryo to a cylinder or a cylinder with a hemisphere on one end (volume $=\pi a^{2} b$ or $\frac{\pi b}{6}\left(3 a^{2}+b^{2}\right)$ where $a$ is the radius of the cylinder and $b$ is the length of the cylinder or cylinder and cup).

Air-dried metaphase spreads were prepared from whole egg cylinders by treating with $1 \%$ sodium citrate for $10 \mathrm{~min}$, fixing with methanol :acetic acid $(3: 1 \mathrm{v} / \mathrm{v})$, and dissociating in $60 \%$ acetic acid on a slide at $60^{\circ} \mathrm{C}$.

\section{Litters at $9 \frac{1}{2}, 10 \frac{1}{4}$ and $10 \frac{1}{2}$ days}

Conceptuses were removed at $14: 00 \mathrm{~h}$ on the 10th day for $9 \frac{1}{2}$-day litters and at $08: 00 \mathrm{~h}$ and $14: 00 \mathrm{~h}$ on the 11 th day for $10 \frac{1}{4}-$ and $10 \frac{1}{2}$-day litters. The fetuses were dissected out in Hepesbuffered Minimum Essential Medium (Flow Laboratories, Irvine, U.K.) and freed of fetal membranes. Somites were counted in the $9 \frac{1}{2}$-day group. The fetuses were transferred in medium to an aluminium weighing pan, and the fluid was withdrawn using the corner of a tissue, before weighing on a Cahn electrobalance. The placentas were mopped dry on a tissue before weighing.

Air-dried metaphase spreads were prepared from yolk sacs by the technique of Evans, Burtenshaw \& Ford (1972) except that after treatment with $60 \%$ acetic acid the detached cells were washed with methanol:acetic acid $(3: 1 \mathrm{v} / \mathrm{v})$ and then air-dried at room temperature. For some litters the amnions were processed for sex chromatin scoring, using the same procedure as for yolk sacs, except that the hypotonic treatment was omitted. Sex chromatin was scored following staining with toluidine blue.

\section{Litters at $12 \frac{1}{4}-18 \frac{1}{2}$ days}

The pregnant mice were killed at $08: 00 \mathrm{~h}$ on the 13 th day or at $14: 00 \mathrm{~h}$ on the 13 th, $15 \mathrm{th}, 17 \mathrm{th}$ and 19th day of pregnancy. The fetuses (freed of membranes) and their placentas were mopped dry on a tissue before weighing on an Oertling R20 pan balance.

Air-dried metaphase spreads were prepared from small pieces of liver taken from female fetuses (identified as females from gonad morphology) using the procedure described above for yolk sacs.

\section{Scoring chromosome preparations}

Four consecutive counts of 39 chromosomes were accepted as sufficient evidence for an XO. XX conceptuses could be clearly differentiated from XY conceptuses at $7 \frac{1}{4}$ days without recourse to banding because the $Y$ is easily recognizable by the criteria described by Ford (1966). In $9 \frac{1}{2}-10 \frac{1}{2}$-day litters XX females were identified by trypsin-Giemsa banding (Papaioannou, Evans, Gardner \& Graham, 1979) or from their sex chromatin-positive amnion cells.

Half the XX fetuses will be heterozygous for the inversion. Trypsin-Giemsa banded preparations from a total of 104 fetuses ranging from $9 \frac{1}{2}-18 \frac{1}{2}$ days post coitum were scored for the presence or absence of the inversion. 


\section{Results}

Because there are major litter effects on growth during pregnancy, all comparisons have been made within litters. Preliminary analyses revealed no differences between XX females with and without the inversion, so the inversion has been ignored when making $\mathrm{XO}-\mathrm{XX}$ comparisons.

In a preliminary report, Burgoyne \& Baker (1981b) observed that the retardation of XO fetal mice is not uniform-occasionally individuals are encountered which are much more severely affected than the norm. Such ' $\mathrm{XO}$ runts' can seriously distort $\mathrm{XO}-\mathrm{XX}$ comparisons, so it was considered necessary to exclude them before analysis of the $\mathrm{XO}$ and $\mathrm{XX}$ growth data. The runts

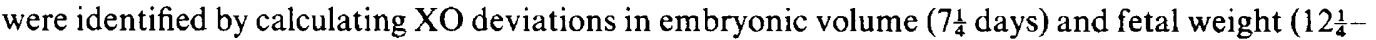
$18 \frac{1}{2}$ days) from XX litter means, and then testing the 'population' of deviations at each gestational age for outliers (Dixon, 1953). Four XO runts were identified: 2 at $10 \frac{1}{4}$ days, 1 at $12 \frac{1}{4}$ days and 1 at $12 \frac{1}{2}$ days. A check on the records of their uterine positions revealed that 3 were next to the cervix, while the 4 th was only one removed from the cervix and was in a crowded horn ( 9 fetuses). By contrast a check for XX runts revealed 3, of which 2 were at the top end of a uterine horn and the third was halfway down.

The form of analysis used throughout for $\mathrm{XO}-\mathrm{XX}$ comparisons is illustrated in Table 1, in which the mean weighted difference in volume between the embryonic part of XO and XX $\mathrm{egg}$ cylinders has been calculated using log-transformed data (the volumes are log-normally distributed). The mean weighted $\log$ difference $(-0.2988)$ is highly significant $\left(t_{19}=5.73\right.$, $P=<0.005)$, indicating that the embryonic volume of an XO egg cylinder was half that of the XX controls (the antilog of $-0.2988 \pm 0.0522$ is 0.50 with $95 \%$ confidence limits of 0.41 and 0.62 ).

Table 1. Analysis of differences in embryonic volume between $\mathrm{XO}$ and $\mathrm{XX}$ egg cylinders at $7 \frac{1}{4}$ days

\begin{tabular}{|c|c|c|c|c|c|c|c|c|c|}
\hline \multirow[b]{2}{*}{ Litters } & \multicolumn{2}{|c|}{ No. of mice } & & \multicolumn{2}{|c|}{ Mean log volumes } & \multirow{2}{*}{\multicolumn{2}{|c|}{$\begin{array}{c}\text { Difference } \\
\left(\mathrm{d}=\overline{\mathrm{X}}_{1}-\overline{\mathrm{X}}_{2}\right)\end{array}$}} & \multirow{2}{*}{$\left(\begin{array}{c}\text { Weighting } \\
\mathrm{w}=\frac{\mathrm{n}_{1} \times \mathrm{n}_{2}}{\mathrm{n}_{1}+\mathrm{n}_{2}}\end{array}\right)$} & \multirow{2}{*}{$\begin{array}{l}\text { Weighted } \\
\text { difference } \\
\quad(w d)\end{array}$} \\
\hline & $\begin{array}{l}\text { XO } \\
\left(n_{1}\right)\end{array}$ & $\begin{array}{l}X X \\
\left(n_{2}\right)\end{array}$ & & $\begin{array}{l}\mathrm{XO} \\
\left(\overline{\mathrm{X}}_{1}\right)\end{array}$ & $\underset{\left(\bar{X}_{2}\right)}{X X}$ & & & & \\
\hline 1 & 2 & 2 & & $2 \cdot 1343$ & $2 \cdot 2101$ & & -0.0758 & 1.00 & -0.0758 \\
\hline 2 & 1 & 6 & & 1.7993 & 2.0248 & & -0.2255 & 0.86 & -0.1939 \\
\hline 3 & 3 & 3 & & 2.0345 & $2 \cdot 3400$ & & -0.3055 & 1.50 & -0.4582 \\
\hline 4 & 2 & 3 & & $1 \cdot 3802$ & 1.9029 & & -0.5227 & $1 \cdot 20$ & $-0 \cdot 6272$ \\
\hline 5 & 2 & 5 & & 1.4831 & 1.7872 & & -0.3041 & $1 \cdot 43$ & -0.4349 \\
\hline \multirow[t]{2}{*}{$\sum$} & 10 & 19 & Mean* & $=1.7663$ & $2 \cdot 0530$ & $\frac{\sum w d}{\sum w}=$ & $=-0.2988 \dagger$ & $\sum w=5.99 \quad \sum w d$ & $=-1.7900$ \\
\hline & & & $\begin{array}{r}\text { s.e.m. } \\
\text { (mm }\end{array}$ & $\begin{array}{l}=0.1479 \\
=0.0584\end{array}$ & $\begin{array}{l}0 \cdot 1003 \\
0 \cdot 1130\end{array}$ & s.e.m. $=$ & $0.0522 \ddagger$ & & \\
\hline
\end{tabular}

* Mean of litter means.

$\dagger$ 'Mean weighted difference'

$\mp$ Calculated using the variance within genotypes within litters.

From the observations on stage of development it was clear that the small size of XO egg cylinders was associated with retarded development. XO egg cylinders were all at the early to midprimitive streak stages while their XX littermates were at mid- to late primitive streak stages or the early neural plate stage. At $9 \frac{1}{2}$ days of gestation the retardation was quantified using somite numbers. The mean weighted XO-XX difference was $-2 \cdot 1 \pm 0 \cdot 8$ somites $(P=0 \cdot 025-0 \cdot 0125)$. Since somite numbers are increasing at a rate of 0.54 somites/h at this time (S. Kalmus \& P. S. Burgoyne, unpublished data), the XO fetuses were $3.9 \pm 1.5 \mathrm{~h}$ behind their XX littermates in development.

The results of the analysis of the log-transformed fetal and placental weight data after exclusion of the runts are given in Table 2. Each line in the table is equivalent to the bottom section of Table 1. In Text-fig. 1 these results are summarized by plotting XO size throughout as a proportion of XX size. Also plotted is the predicted size for XO fetuses if they remained the $3.9 \mathrm{~h}$ behind in 
development which was estimated from the $9 \frac{1}{2}$-day somite data. The fetal weight data show that XO fetuses caught up with their XX littermates between $10 \frac{1}{2}$ and $12 \frac{1}{2}$ days. Additional data were collected at $12 \frac{1}{4}$ days which substantiated this. By $14 \frac{1}{2}$ days the XO fetuses had lagged behind again, but more data are required to confirm this. In marked contrast, the placentas of XO fetuses were initially the same weight as controls, and became significantly heavier than those of controls by $18 \frac{1}{2}$ days.

Table 2. Mean fetal and placental log weights for $\mathrm{XO}$ and $\mathrm{XX}$ mice and the estimated differences between them for the period $9 \frac{1}{2}-18 \frac{1}{2}$ days post coitum

\begin{tabular}{|c|c|c|c|c|c|c|}
\hline \multirow{2}{*}{$\begin{array}{l}\text { Days of } \\
\text { gestation }\end{array}$} & \multicolumn{2}{|c|}{ No. of mice } & \multicolumn{2}{|c|}{ Mean \pm s.e.m. $\log w^{*}(w t$ in $m g)$} & \multirow{2}{*}{$\begin{array}{c}\text { Mean } \pm \text { s.e.m. } \\
\text { weighted } \\
\text { XO-XX difference }\end{array}$} & \multirow{2}{*}{$\begin{array}{c}\text { Significance } \\
\text { of XO-XX } \\
\text { difference }(P)\end{array}$} \\
\hline & xo & $\mathbf{X X}$ & XO & $\mathrm{xx}$ & & \\
\hline \multicolumn{7}{|l|}{ Fetal } \\
\hline $9 \frac{1}{2}$ & 10 & 18 & $0.356 \pm 0.06(2.27)$ & $0.484 \pm 0.02(3.05)$ & $-0.124 \pm 0.053$ & $0.025-0.0125$ \\
\hline $10 \frac{1}{2}$ & 13 & 40 & $1.276 \pm 0.02(18.86)$ & $1.345 \pm 0.02(22.13)$ & $-0.071 \pm 0.020$ & $0.0025-0.0005$ \\
\hline $12 \frac{1}{4}$ & 7 & 22 & $1.924 \pm 0.01(84.0)$ & $1.922 \pm 0.02(83.5)$ & $-0.002 \pm 0.021$ & NS \\
\hline $12 \frac{1}{2}$ & 15 & 41 & $2.035 \pm 0.02(108.4)$ & $2.035 \pm 0.01(108.4)$ & $-0.005 \pm 0.011$ & NS \\
\hline $14 \frac{1}{2}$ & 18 & 30 & $2.461 \pm 0.03(288.8)$ & $2.494 \pm 0.01(311.7)$ & $-0.039 \pm 0.014$ & $0.005-0.0025$ \\
\hline $16 \frac{1}{2}$ & 13 & 30 & $2 \cdot 847 \pm 0.03(703 \cdot 1)$ & $2.869 \pm 0.02(739.8)$ & $-0.025 \pm 0.011$ & $0.0125-0.001$ \\
\hline $18 \frac{1}{2}$ & 13 & 18 & $3 \cdot 142 \pm 0 \cdot 02(1386 \cdot 2)$ & $3 \cdot 155 \pm 0.02(1429 \cdot 6)$ & $-0.010 \pm 0.018$ & NS \\
\hline \multicolumn{7}{|l|}{ Placental } \\
\hline $9 \frac{1}{2}$ & 10 & 21 & $1.473 \pm 0.01(29.7)$ & $1.473 \pm 0.01(29.7)$ & $-0.003 \pm 0.016$ & NS \\
\hline $10 \frac{1}{2}$ & 13 & 40 & $1.645 \pm 0.02(44.2)$ & $1.654 \pm 0.01(45 \cdot 1)$ & $-0.009 \pm 0.010$ & NS \\
\hline $12 \frac{1}{2}$ & 15 & 40 & $1.933 \pm 0.02(85.8)$ & $1.908 \pm 0.01(81.0)$ & $+0.016 \pm 0.018$ & NS \\
\hline $14 \frac{1}{2}$ & 18 & 30 & $2 \cdot 114 \pm 0.03(129 \cdot 9)$ & $2 \cdot 077 \pm 0.01(119 \cdot 3)$ & $+0.036 \pm 0.020$ & NS \\
\hline $16 \frac{1}{2}$ & 13 & 30 & $2.141 \pm 0.03(138.2)$ & $2.103 \pm 0.02(126.9)$ & $+0.032 \pm 0.022$ & NS \\
\hline $18 \frac{1}{2}$ & 13 & 18 & $2.132 \pm 0.03(135.5)$ & $2.037 \pm 0.03(108.9)$ & $+0.098 \pm 0.025$ & $<0.001$ \\
\hline
\end{tabular}

* Means of litter means.

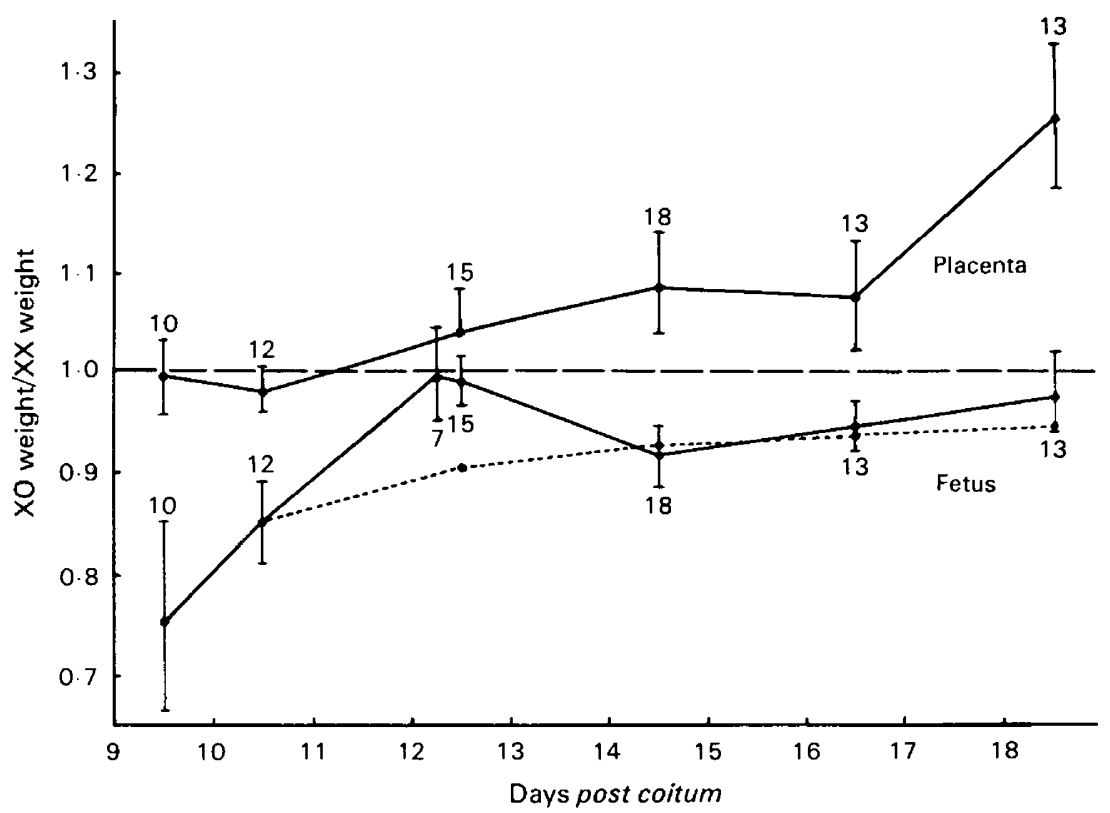

Text-fig. 1. XO fetal and placental weights plotted as proportions of XX weights for the period $9 \frac{1}{2}-18 \frac{1}{2}$ days of gestation. Bars indicate standard errors and the number of XOs contributing data is indicated for each point. The broken line, calculated from the XX growth data, indicates the expected size of XO fetuses if they remained the $3.9 \mathrm{~h}$ behind in development which had been estimated from the $9 \frac{1}{2}$-day somite data. 


\section{Discussion}

Our results reveal that $\mathrm{XO}$ mice were already lagging behind their $\mathrm{XX}$ sibs in development by the 8 th day of pregnancy. This lag continued until $10 \frac{1}{2}$ days of gestation, but there was evidence of catch-up growth between $10 \frac{1}{2}$ and $12 \frac{1}{2}$ days. However, this 'catch-up' was not maintained, which is in keeping with the finding that XO mice are underweight at birth (Burgoyne et al., 1983).

XO monosomy may have a continuous effect on development, or the growth profile from $7 \frac{1}{4}$ to $18 \frac{1}{2}$ days may simply be a result of the retardation present at $7 \frac{1}{4}$ days. Tarkowski (1959) has described the development of single blastomeres from 2-cell mouse embryos. These 'half embryos' continue to develop according to their original programme and consequently form half-sized blastocysts; but development subsequently lags behind that of controls with the result that by the primitive streak stage development and size have become co-ordinated. The lag remains for 2 or 3 days, and then an apparent acceleration of growth and development brings them back in line with controls by about $12 \frac{1}{2}$ days. Tarkowski's (1959) experiments suffered from inadequate controls, but taken at face value the development of these chromosomally normal 'half embryos' from the primitive streak stage onwards mimics XO development. Thus we tentatively suggest that XO mouse conceptuses are not being constrained by their genotype during the period studied.

The origin of the developmental lag already present at $7 \frac{1}{4}$ days is clearly of interest. Why should $\mathrm{XO}$ embryos be affected when one $\mathrm{X}$ is sufficient for $\mathrm{XY}$ embryos? It may be that the $\mathrm{X}$ and $\mathrm{Y}$ chromosomes share some genes in common (see Burgoyne, 1982) and that these are required in double dose in the early embryo. However, the XO embryos in the present study also differ from XY embryos in having a paternal rather than a maternally derived $X$ chromosome. A study of the development of $\mathrm{XO}$ embryos with a maternally derived $\mathrm{X}$ is needed to help resolve this question.

At first, the occurrence of XO 'runts' preferentially located near the cervix is puzzling, since XX runts in this study and the runts described by McLaren \& Michie (1960) were preferentially located at the top of a uterine horn. However, it is clear from information on uterine position in a separate study (P. S. Burgoyne \& S. Kalmus, unpublished data) that at $9 \frac{1}{2}-10 \frac{1}{2}$ days a cervical location is associated with lowered XX and XY fetal and placental weights. This effect is not seen late in

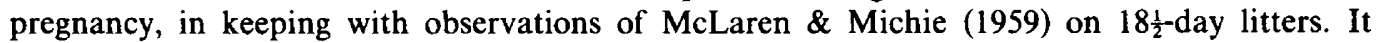
therefore seems that there is a genotype-environment interaction for $\mathrm{XO}$ runts, with the less favourable cervical position exacerbating the developmental deficiencies associated with XO monosomy.

Interpretation of the data on placental size is complicated by the fact that the placenta has fetal and maternal components. Presumably the increase in size of XO placentas relative to XX placentas in late gestation involves the fetal contribution because the fetal contribution dominates at this stage. A similar size advantage is seen in XY placentas at this time (P. S. Burgoyne \& E. P. Evans, unpublished). It will require histological study to determine whether the fetal contribution to the placenta is normal at the earlier stages.

Do these observations on the early development of the XO mouse have any relevance to the development of human XO conceptuses? Boué, Philippe, Giroud \& Boué (1976) have recorded the stage of development attained by human $\mathrm{XO}$ abortuses. The mean developmental age judged from the embryonic remnants and/or placenta was 6 weeks after fertilization. In about two-thirds of the specimens there was little embryonic tissue, but in most of the remainder there was an essentially normal embryo of 40-45 days of development. There was a discrepancy of several weeks between the developmental and gestational ages, which Boué et al. (1976) have interpreted as being due to retention in utero after developmental arrest. In the light of our observations on the XO mouse it seems likely that much of the discrepancy may in fact be due to a much earlier developmental retardation, after which development continues.

The most striking feature of human XO development is the $99 \%$ loss by spontaneous abortion during pregnancy (see Polani, 1981), which contrasts with a negligible pregnancy loss in the mouse (P. S. Burgoyne \& E. P. Evans, unpublished). This difference may be related to the different strategies for the maintenance of pregnancy in the two species. In the mouse ovarian steroids are 
involved throughout gestation, whereas in man placental steroids become essential towards the end of the first trimester. Boué, Boué \& Spira (1974) argue that the peak of spontaneous abortion around 12 weeks after the last menstrual period is due to the cessation of ovarian support at this time, those conceptuses with placental hormone insufficiency being aborted. Our belief is that human XO embryos which reach 6 weeks of development are inherently viable, but that the placenta, possibly because of immaturity, is in most cases unable to maintain the pregnancy.

It is clear from descriptions of XO fetuses surviving beyond the first trimester (Singh \& Carr, 1966; Singh, 1970; Boué et al., 1976) and from information on the $1 \%$ that survive to term (Simpson, 1976) that there are a number of anomalies, in addition to small stature and sterility, which are associated with XO monosomy in man. Among the more frequently encountered are skeletal abnormalities, webbing of the neck, and lymphoedema of the hands and feet at birth. Such anomalies have not been described in the XO mouse. It is possible that the initial developmental retardation is much greater in the human $\mathrm{XO}$ fetus, and that the anomalies arise during a catch-up period. In the mouse severe retardation is followed by some developmental mismatch during the catch-up period (Snow, Tam \& McLaren, 1981; Tam, 1981), with consequent malformations. Alternatively, the anomalies could be a consequence of damage incurred during a near-failure of the pregnancy, resulting from the same placental insufficiency which more usually results in abortion.

We thank Karen Holland and Mike Burtenshaw for technical assistance. P.P.L.T. was supported by a British Commonwealth Scholarship. E.P.E. is a member of the M.R.C. external staff.

\section{References}

Boué, J.G., Boué, A. \& Spira, A. (1974) Evolution des dosages hormonaux urinaires dans les grossesses avec anomalies chromosomiques lethales ou viables. In L'Exploration Hormonale dans la Surveillance Biologique de la Grossesse Humaine, pp. 167-189. Ed. R. Scholler. SEPE, Paris.

Boué, J., Philippe, E., Giroud, A. \& Boué, A. (1976) Phenotypic expression of lethal chromosomal anomalies in human abortuses. Teratology 14, 3-20.

Burgoyne, P.S. (1982) Genetic homology and crossing over in the $\mathrm{X}$ and $\mathrm{Y}$ chromosomes of mammals. Hum. Genet. 61, 85-90.

Burgoyne, P.S. \& Baker, T.G. (1981a) Oocyte depletion in XO mice and their XX sibs from 12 to 200 days post partum. J. Reprod. Fert. 61, 207-212.

Burgoyne, P.S. \& Baker, T.G. (1981b) The XO ovarydevelopment and function. In Development and Function of Reproductive Organs, pp. 122-128. Eds A. G. Byskov \& H. Peters. Excerpta Medica, Amsterdam.

Burgoyne, P.S. \& Biggers, J.D. (1976) The consequences of X-dosage deficiency in the germ line: impaired development in vitro of pre-implantation embryos from XO mice. Devl Biol. 51, 109-117.

Burgoyne, P.S., Evans, E.P. \& Holland, K. (1983) XO monosomy is associated with reduced birth weight and lowered weight gain in the mouse. J. Reprod. Fert. 68, 381-385.

Cattanach, B.M. (1962) XO mice. Genet. Res. 3, 487-490.

Chen, A.T.L., Chan, Y.K. \& Falek, K. (1971) The effects of chromosome abnormalities on birth weight in man. I. Sex chromosome disorders. Hum. Hered. 21, 543-556.
Deckers, J.F.M. \& van der Kroon, P.H.W. (1981) Some characteristics of the XO mouse (Mus musculus L.). I. Vitality: growth and metabolism. Genetica 55, 179185.

Dixon, W.J. (1953) Processing data for outliers. Biometrics 9, 74-89.

Evans, E.P. \& Phillips, R.J.S. (1975) Inversion heterozygosity and the origin of XO daughters of $\mathrm{Bpa} /+$ female mice. Nature, Lond. 256, 40-41.

Evans, E.P., Burtenshaw, M.D. \& Ford, C.E. (1972) Chromosomes of mouse embryos and newborn young: preparations from membranes and tail tips. Stain Technol. 47, 229-234.

Ford, C.E. (1966) The murine Y-chromosome as a marker. Transplantation 4, 333-334.

Lyon, M.F. \& Hawker, S.G. (1973) Reproductive lifespan in irradiated and unirradiated XO mice. Genet. Res. 21, 185-194.

McLaren, A. \& Michie, D. (1959) The spacing of implantations in the mouse uterus. Mem. Soc. Endocr. 6, 65-74.

McLaren, A. \& Michie, D. (1960) Congenital runts. In Congenital Malformations (Ciba Fon Symp.), pp. 178194. Eds G. E. W. Wolstenholme \& M. O'Connor. Churchill, London.

Papaioannou, V.E., Evans, E.P., Gardner, R.L. \& Graham, C.F. (1979) Growth and differentiation of an embryonal carcinoma cell line (c1456). J. Embryol. exp. Morph. 54, 277-295.

Phillips, R.J.S., Hawker, S.G. \& Moseley, H.J. (1973) Bare-patches, a new sex-linked gene in the mouse, associated with a high proportion of $\mathrm{XO}$ females. I. 
A preliminary report of breeding experiments. Genet. Res, 22, 91-99.

Polani, P.E. (1974) Chromosomal and other genetic influences on birth weight variation. In Size at Birth (Ciba Fdn Symp. No. 27 (new series)), pp. 127-164. Eds K. Elliott \& J. Knight. Elsevier/Excerpta Medica, North Holland, Amsterdam.

Polani, P.E. (1981) Abnormal sex development in man. I. Anomalies of sex-determining mechanisms. In Mechanisms of Sex Differentiation in Animals and Man, pp. 465-547. Eds C. R. Austin \& R. G. Edwards. Academic Press, London.

Simpson, J.L. (1976) Disorders of Sexual DifferentiationEtiology and Clinical Delineation. Academic Press, New York.

Singh, R.P. (1970) Hygroma of the neck in XO abortuses. Am. J. clin. Path. 53, 104-107.
Singh, R.P. \& Carr, D.H. (1966) The anatomy and histology of XO human embryos and fetuses. Anat. Rec. 155, 369-384.

Snow, M.H.L., Tam, P.P.L. \& McLaren, A. (1981) On the control and regulation of size and morphogenesis in mammalian embryos. In Levels of Genetic Control in Development, pp. 201-217. Eds S. Subtelny \& U. K. Abbott. Alan R. Liss, Inc., New York.

Tam, P.P.L. (1981) The control of somitogenesis in mouse embryos. J. Embryol. exp. Morph. 65 (Suppl.), 103-128.

Tarkowski, A.K. (1959) Experimental studies on regulation in the development of isolated blastomeres of mouse eggs. Acta theriol. 3, 191-267.

Welshons, W.J. \& Russell, L.B. (1959) The Y-chromosome as the bearer of male determining factors in the mouse. Proc. natn. Acad. Sci. U.S.A. 45, 560-566.

Received 11 November 1982 